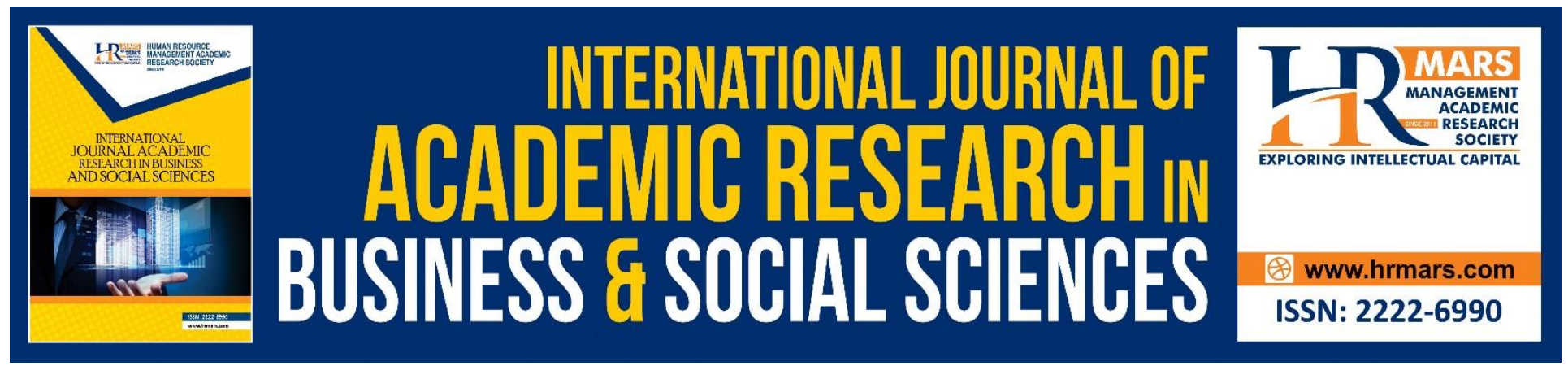

\title{
Singapore and Korea Towards Creative Economy in 21 st Century: Comparative Analysis of Higher Education in Singapore and South Korea
}

\section{Roland Attila Csizmazia}

To Link this Article: http://dx.doi.org/10.6007/IJARBSS/v9-i1/5426

DOI: $\quad 10.6007 /$ IJARBSS/v9-i1/5426

Received: 19 Dec 2018, Revised: 27 Jan 2019, Accepted: 05 Feb 2019

Published Online: 08 Feb 2019

In-Text Citation: (Csizmazia, 2019)

To Cite this Article: Csizmazia, R. A. (2019). Singapore and Korea Towards Creative Economy in 21st Century: Comparative Analysis of Higher Education in Singapore and South Korea. International Journal of Academic Research in Business and Social Sciences, 9(1), 506-525.

\section{Copyright: (C) 2019 The Author(s)}

Published by Human Resource Management Academic Research Society (www.hrmars.com) This article is published under the Creative Commons Attribution (CC BY 4.0) license. Anyone may reproduce, distribute, translate and create derivative works of this article (for both commercial and non-commercial purposes), subject to full attribution to the original publication and authors. The full terms of this license may be seen at: http://creativecommons.org/licences/by/4.0/legalcode

\section{Vol. 9, No. 1, 2019, Pg. 506 - 525}

Full Terms \& Conditions of access and use can be found at http://hrmars.com/index.php/pages/detail/publication-ethics 




\title{
Singapore and Korea Towards Creative Economy in 21 st Century: Comparative Analysis of Higher Education in Singapore and South Korea
}

\author{
Roland Attila Csizmazia
}

Assistant Professor, Academy of Advanced Studies, Kwangwoon University, Seoul, Republic of Korea

\section{Abstract}

This paper analyzes the most recent policies and trends in South Korean and Singaporean higher education. The main objective of this comparative analysis is to show similarities between South Korean and Singaporean strategies for their higher education structures, despite striking differences between the emergence levels of the two higher education systems. The comparison is designed to identify their most recent past, current efforts to progress in decentralization of tertiary education towards creative economy; to develop policies in order to increase competitiveness of domestic "world-class" universities; to attract a high number of international students, particularly full-tuition paying students; to attract and retain foreign talents. Certain programs, such as the provision of bonded scholarship for international students in Singapore and WCU in Korea, may appear controversial. Accordingly, the fine-tuning of referring policies and drivers is of vital importance.

Keywords: Internationalization, Decentralization In Education, World-Class Universities, Higher Education Policies, Liberalization

\section{Introduction}

Both Singapore and South Korea inherited poor economic conditions from the colonial period, but they managed to achieve rapid economic growth. The only capital they could use was the human capital. Obviously, their governments treated it with exceptional attention to raise productivity and later to create and enhance innovation capacities (Gopinathan, 2007). They regarded from the early years investment and intervention in education as necessary to emerge economically. Their education went through several development cycles (survival-driven, efficiency-driven, ability-based, and most recently demand-oriented value-driven phases) at a faster pace than in Western countries (OECD, 2016). In their efforts to build competitive advantages through science, technology, and R \& $\mathrm{D}$, both higher education and corporate education have played an important role.

Education services were defined and classified within the four modes of General Agreement on Trade in Services (GATS), which is regarded as part of globalization, it is a multilateral agreement and a 
systematic framework under the WTO. It came into effect in 1995 with the aim to increase trade in services through liberalization. Along with many public services, education and also higher education have become more and more subject to decentralization, commodification, massification, marketization and also corporatization. Globalization and internationalization have driven governments to become progressively proactive rather than responsive and more flexible. They recently have accelerated decentralization approaches and deregulations in public services with the aim also to discover alternative financial sources. Singapore's desire to become 'Boston of the East' from 2000 (MOE, 2000; Mok, 2003 \& 2006; Sidhu \& Yeoh, 2011; Basillote et al., 2016), her headquarter strategy and her drive for a knowledge-based economy require the steps to attract talents from all over the world and to strive for a large share of global education market through her renowned Global Schoolhouse project (Shin, 2014; Csizmazia, 2016). The Global Schoolhouse project is a long-term dynamic strategic plan to raise quality of education in Singapore and to facilitate universities to compete with established world class universities. The governmental involvement has manifested several times as intervention. Although decentralization efforts have been taken, regulations enacted represent higher degree of (re-)centralization (Lee \& Gopinathan, 2008 \& 2015; Mok, 2003, Moon \& Kim, 2001). Similarly, Korea's development and in tandem with that changing societal demands for upward mobility triggered the decentralization process in education. Despite of rising autonomy in higher education, the degree of institutional autonomy could not reach a satisfactory level due to policies which highlight and target only a few basic and applied sciences rather than provide autonomy to universities, e.g., WCU, Brain Korea 21 (Moon \& Kim, 2001). Both countries started to emphasize the importance of lifelong learning to their citizens to establish a human capital that is flexible and is able to respond to technological development. The most recent decentralized efforts in Korea are related to the Songdo Global University Campus (SGUC) and Jeju Global Education Campus projects (Kang, 2010).

Newly industrialized countries, such as Singapore and South Korea, showed an amazing development in their economies despite of the Asian financial crisis in 1997-1998. Although many scholars analyzed both countries one by one. A comparative analysis can not only reveal details for the countries, but also which of the elements in development they used commonly and which of the challenges they could fight successfully. Therefore, the author selected the method of comparative analysis in order to manifest similarities as well as differences, which led to different quality level of economies and tertiary education sectors in these two countries. This comparative analysis is separated into four main sections which reveal similarities as well as differences in the two countries. The first section covers the governments' strategies towards decentralization and expansion, and observes that in both countries, decentralization evolved into re-centralization as the governments, concerned as they were about education standards and quality, put pressures on universities to provide value. The second section describes in a brief snapshot how the two countries targeted internationalization of higher education most recently. The third section enumerates the major policies, common source of difficulties in opting for attracting international full-tuition paying students the promotion of academic research and the academic involvement in innovations, start-ups and spin-offs to strengthen SMEs. The fourth section ends the analysis with a conclusion considering implications for further research. 
INTERNATIONAL JOURNAL OF ACADEMIC RESEARCH IN BUSINESS AND SOCIAL SCIENCES

Vol. 9, No. 1, Jan, 2019, E-ISSN: 2222-6990 @ 2019 HRMARS

\section{Decentralization and Expansion of Higher Education}

One of the main driving factors in the public sector and policy making has recently been the globalization. Globalization forced both the governments and higher education to respond to rapidly changing demands, such as demand for efficiency and quality. Carnoy asserted (2000) that globalization gave educational reforms a financial pressure. On the one hand, it nourished extensive privatization, marketization and commercialization of higher education and also decentralization in the field of education. On the other hand, the mobility of both professionals and students increased. Three main types of decentralization can be distinguished, i.e., political, administrative and market related decentralization.

The subject of educational decentralization belongs to the administrative decentralization. In a broad sense, it refers to transfer and redistribution of authority, responsibility and financial sources for the provision of public services among different levels of government. Tatto (1999) asserted that the range of decentralization in education services is wide and cannot be described as a one-way decentralization since in some cases "centralized decentralization" or re-centralization may be triggered off. The major forms of administrative decentralization are: deconcentration (transfer of work but not the authority to other units within the organization); delegation (transfer of decisionmaking authority from higher to lower units within the hierarchy, however authority can be withdrawn); and devolution (transfer of authority to an autonomous unit that may act independently) (Mok, 2003). Although all three major forms can be observed in both countries, policies and projects suggest a high level or also increasing level of centralization at the same time, i.e., centralization of strategic leadership in tandem with operational decentralization, is noticeable in educational governance (Mok, 2003).

Singapore's government has operated as an 'entrepreneurial government' long before the term was coined by Ferlie et al. (1996). Based on its meritocratic and technocratic governance style the government has continuously adopted policies which served efficiency and competitiveness (Tan, 2008). Similarly, the governments in Korea included technocrats over the time, yet consistence has not played a central role in governance. In Singapore the government has always reacted on worldwide changes and crises flexibly to balance between growth and stability. It also attempted to become proactive in reforming the education to serve corporate needs for human capital. Not only the political and economic environment, but also the education system was affected by this guidance of the government. The careful monitoring of changing economy involvement can also be revealed by the guidance of education development.

Until the 1980s the emphasis lied on the extension of education aiming the needs for manpower by the changing environment of the economy. From 1990s the focus shifted from quantitative to qualitative development with policies promoting the establishment of university education (Lee \& Gopinathan, 2008; Adeusi \& Aluko, 2017). Two educational strategies were developed for higher education: The government continued its involvement to upgrade and provide tertiary education with academic standards, research quality, resource endowment, and managerial efficiency to be able to compete with renowned Western universities. It was also determined to develop a regional hub for international talented and full-tuition fee paying students (Natarajan et al., 2016). To progress with the goals it offered more autonomy to universities in exchange for tightened control and it has become sensitive about the quality and standards. Consequently, it has given a certain degree of 
INTERNATIONAL JOURNAL OF ACADEMIC RESEARCH IN BUSINESS AND SOCIAL SCIENCES

Vol. 9, No. 1, Jan, 2019, E-ISSN: 2222-6990 @ 2019 HRMARS

autonomy for a higher level of accountability and transparency to the public at public universities to maximize 'value for money'. According to the University Autonomy, Governance and Funding (UAGF) Preliminary Report prepared by Ministry of Education in 2005, the autonomy supports that universities:

- Increase efficiency by introducing enhanced accountability framework;

- Respond flexibly to challenges and opportunities in the competitive global university environment;

- Differentiate and specialize themselves to foster excellence;

- Convert themselves through corporatization into 'non-profit' companies with elevated responsibility towards clearly specified stakeholders;

- Encourage faculties to take on responsibility for management activities, e.g., decision-making for curricula and academic quality; and

- Build alumni and support network by strengthening communications and building deepened sense of community among stakeholders (MOE, 2005).

Accordingly, the government established a systematic accountability framework and the two public universities - National University of Singapore (NUS) and Nanyang Technological University (NTU) received extensive autonomy in their financial management. This step also disconnected the academic staff from civil service salary schemes so that the automatic annual incremental growth could be replaced by performance-based increases (Lee \& Gopinathan, 2008). Furthermore, the Singaporean government sought to avoid overreliance of public universities on governmental funding and established University Endowment Funds. Several other endowment funds were also created partly through donations, e.g., a donation of $\$ 1.2$ million from the charity arm of SCCCl (Sing apore Chinese Chamber of Commerce and Industry) to five universities (Teng, 2016), and by private contribution which includes savings through payments into an endowment plan.

The administration initiated a top-down restructuring of university sector in 2003 with the goal to transform NUS into a multi-campus university, NTU into a comprehensive university and continued to expand Singapore Management University (SMU) which was established as a joint venture 'experiment in diversity' between Singapore and Wharton School at the University of Pennsylvania and was opened as a "private" university in 2000 (MOE, 2003). To progress into "global knowledge enterprise" within the frames of the Global Schoolhouse project three more 'autonomous-public' universities were established in collaboration with world-class universities:

- The Singapore University of Technology and Design (SUTD) - established in 2012 - with Massachusetts Institute of Technology (MIT) and Zhejiang University (ZJU) with the aim to cultivate technically educated leaders and innovators for society and collaborated in education, research, student (Toh, 2012);

- Singapore Institute of Technology (SIT), established in 2009, offers degree programs and also own applied degrees in partnership with reputable overseas universities in engineering and applied sciences, health sciences, design, and interactive digital media. Many of the degrees are offered for polytechnic upgraders (MOE, 2016).

- The earlier UniSIM now SUSS. The institute was a member of the Singapore Institute of Management has targeted working professionals and adult learners with flexible practiceoriented part time programs and has started to offer full-time degree programs from 2014. In 
INTERNATIONAL JOURNAL OF ACADEMIC RESEARCH IN BUSINESS AND SOCIAL SCIENCES

Vol. 9, No. 1, Jan, 2019, E-ISSN: 2222-6990 @ 2019 HRMARS

2017 UniSIM was renamed to Singapore University of Social Sciences (SUSS) as part of the ongoing re-structuring to transform to the newest autonomous university that belongs to the ambit of the Ministry of Education in Singapore (UniSIM, 2017).

The restructuring of existing universities and the foundation of new universities were intended to serve the necessity to cultivate highly-skilled workforce to progress into future and match the demand of knowledge-based creative economy. Hence, with careful respect to the high quality of tertiary education, the Ministry of Education only gradually planned to increase the cohort participation rate (CPR) from $21 \%$ in 2003 to 25\% in 2010 (MOE, 2003) and to 30\% in 2015 and eventually explored the impact to increase CPR to 40\% by 2020 (MOE, 2012).

Similarly to Singapore, the South Korean economy required a continuously emerging education towards knowledge based economy. While in Singapore the quantitative expansion occurred from 1980 and qualitative expansion has been prioritized before quantitative expansion, the latter, i.e., massification, occurred up to the 1990s and foreran the qualitative improvement started in 1995 in South Korea. The development in education can be categorized in the same fashion like by the OECD study on Singapore (OECD, 2016), i.e., survival-driven in the 1960s, efficiency-driven from the 1970s, ability-based 1980s, and most recently demand-oriented value-driven phase from the 5.31 May Plan in 1995 that includes the first internationalization goals, i.e., efforts towards demand orientation. As a direct response to the severe impact of the Asian financial crisis (1997-98) the government had to shift focus towards knowledge-based economy and introduced the Brain Korea 21 (BK 21) I-II, BK 21 PLUS as well as the Study Korea and World-Class University (WCU) projects. The latest establishment during the Park administration was introduced as the 'University for a Creative Korea' project in 2014 (Green, 2015).

The education system represents a stakeholder structure that is highly different from the ones in the OECD countries. About $86 \%$ of the higher education institutions were in private hands and about $77 \%$ of university students were enrolled in these institutions in 2016 (KEDI, 2016). Nevertheless, a strong uniformity is ensured by the government in both public and private higher education. The South Korean Ministry of Education has maintained a direct control over the institutions irrespective of their funding patterns. Private universities have been regulated by the Private School Law (Kim, 2007). The law was revised to accommodate the proposals of the Korean Teachers and Education Workers' Union to oblige the private institutions to submit records of personnel changings, such as appointments, promotions and dismissals, and it also requires them to disclose financial data to the government (Kim, 2007 \& Bahk, 2013). Both revisions underline the strong regulatory role of the government.

The continuous commitment to the projects in Singapore allows the stakeholders to create and follow long-term goals. Unfortunately, over the time this could not be observed in Korea. Quite the contrary, the Korean governments seem to promise radical improvements, which may lead to redundancies and inefficiencies as well as excessive expectations for the results. Additionally, the projects launched by the former governments may be either completely eliminated or significantly modified (Han et al., 2018). In such a case, scholars' qualitative performance might be restrained as longer researches become discouraged.

Yet, in both high inefficiencies represent a problem in education. Families carry the heavy burden of private tutoring costs. Parents invest into education as they believe that their children can enroll at 
one of the top universities and can then later get a high-paying job (Christensen, 2015 and Hultberg et al., 2017). The reason for this lies in the Confucian heritage of both countries. Korea has an approach of "no child left behind" and 98\% of population between 25 and 34 attained upper secondary school and $70 \%$ also obtained tertiary education argues (OECD, 2018). In Singapore 'kiasuism' ('fear of dropping out') influences parents' attitude. Singaporean children are 'categorized' from early childhood. Consequently, it is hard to obtain a post-secondary degree (and university degree is even harder); only $54.2 \%$ of the population over age 25 has a post-secondary diploma (Singstat, 2018).

Kim (2012) remarks two 'representative features' egalitarian ideal and zeal for the education in South Korea. Egalitarianism has been pursued since the introduction of modern education, i.e., the leaders have been keen to ensure education irrespective of gender, religion, geographic location, or socioeconomic status. 2016 Policy Plans of the Ministry of Education also reinforce that through 'Happy Education for All' the equity has to be ensured from the early childhood education (SK-MOE, 2016). Although, children's education is free, the admission regulations require high competition among students to gain enrolment at one of the renowned universities in Korea. The heavy reliance on Korean academies 'hagwons', i.e., private tutoring institutions, has put a burden on parents. The 5.31 First Educational Reform Plan has already addressed this problem. Although, the Korean governments intervened several times, the interventions has not come up with the expectations yet (Golden \& Toledo, 2016). Education has been identified in countries with Confucian heritage as the chance to move up in the social hierarchy. Accordingly, zeal for education exists in both countries, Singapore and South Korea (Lee, 2008 \& Christensen, 2015). To these features Lee (2008) adds the followings in Korean education:

- Rapid quantitative expansion in all education levels;

- Efficiency in policy implementation - due to top-down hierarchy;

- Extreme competition for college/university entrance;

- Highly centralized educational administration causing lack of diversity and autonomy;

- Low confidence in public school education; and

- High private costs for tutoring to get enrolled and in tertiary education.

A few of the above characters obviously reflect the shortcomings and the power relations within the higher education. In the case of competition, it is meant to be challenging and supportive in orientation, creativity and advancement, its exaggeration leads to exhaustion, loss of creativity before it could be really cultivated. Additionally, the lack of autonomy of private universities in their management and academic affairs, e.g., student admission quotas; qualification of teaching staff; and development of curricula leads to reproduction of a single system of an established public university and discourage all the efforts of diversification and specialization.

The continuous commitment to the projects in Singapore allows the stakeholders to create and follow long-term goals. Unfortunately, over the time this could not be observed in Korea. Quite the contrary, the South Korean higher education has largely been influenced by the elected governments and the introduction of policies might lack of continuity. Leaders have often attempted to respond to societal and environmental changes in education with quick-fixes rather than taking a proactive role. The Korean governments attempt to promise radical improvements, which may lead to redundancies and inefficiencies as well as excessive expectations for the results. Additionally, the projects launched by 
the former governments may be either completely eliminated or significantly modified (Han et al., 2018). In such a case, scholars' qualitative performance might be restrained as longer researches become discouraged. Nevertheless, globalization depicted that the old higher education governance was no longer appropriate and feasible. The reforms after 1995 imply strong future orientation. Before the 5.31 reform was introduced in 1995, the government admitted openly that the efforts failed to bring autonomy into the education system (Kwak, 2001). The 5.31 Plan was released as a comprehensive framework with nine core tasks and 48 specific tasks to modernize education and prepare the people for the 21st century along the principles of deregulation, competition and marketization. The nine core tasks included facilitating "lifelong learning" for every citizen by introducing the New Education System for 'Edutopia', diversification and specialization of universities, transforming of a democratic and autonomous school community, emphasis on humanity and creativity in curricula, i.e., consumer orientation, and increasing educational budget since the direct public expenditure for educational institutions stood at 4.4\% of the GDP in 1997, one of the lowest figure among OECD countries (Lee, 2000 \& OECD, 2000). The 1997-98 East Asian financial crisis has hit Korea severely and actually paved the way for further well-considered reforms. The government announced BK 21 and World-Class University Projects for the higher education. Both reform projects are aspired by potential economic growth and heavily depend on government funds rather than fostering innovation in collaboration with the industry (Altbach, 2000). The consequence of such a huge investment was that the number of scientific publications, the number of patent registrations rose steeply, but none could reproduce Boston as "Boston of the East".

The centralized control over tertiary education institutions have rather intensified through the competition for funding in both countries. The 2015 Plan for Ministry of Education in Korea reveals that the government have remained in a central position in regard to funding and student admission. Nevertheless, it also depicts a shift towards commercialization of research output by collaboration with the respective industries (MOE Korea, 2015).

In the university reform plan 2016 the Ministry of Education (2016) roughly described the goal to increase autonomy and accountability of universities and intends to develop public universities, to specialize existing universities, to promote industry-universities ties in tandem with the employment trends, to raise social responsibility and transparency of private universities (MOE Korea, 2016). Such a plan further excavates the centralized efforts, while promising higher level of autonomy.

Even though decentralization took place in both countries, scholars argue that sufficient autonomy has never been granted to tertiary education institutions compared to renowned institutions in Western countries.

Marketization efforts of Singapore and Korea are a consequence of globalization in order to raise competitiveness not only of the higher education, but also of the related research industries, to raise accountability, while promoting collaboration between higher education and industries, where the industries also participate in financing the education.

\section{Internationalization of Higher Education in Singapore and South Korea}

Knight (2004) defined internationalization of higher education as "the process of integrating an international, intercultural or global dimension into the purpose, functions or delivery of postsecondary education". Findlay and Tierney (2010) identified the first level of internationalization at 
elite universities in advanced countries - with which also Singapore benchmarks public universities in the city-state - and stated the rapid growth of internationally mobile faculty and students. The effect of international mobility can be represented by the quantitative evidence of the 'The Erasmus Impact Study' that proves the support of student mobility on employability and career path of new graduates (European Commission, 2014). Hence, globalization has required universities to interact with other universities worldwide and to invite scholars to enhance value of education through network and infrastructure, to increase employability of students and to be able to compete with other universities both domestically and internationally.

The number of international students and their destinations have been changing dynamically over the years. India and China have been among the major sending countries and UK, USA, Canada and Australia have been the traditional destinations. Most recently numerous students prefer neighboring destinations based on their university rankings, their proximity, the opportunities provided in the host countries and on regional programs like Common Space of Higher Education inspired by the European Higher Education Area and the ERASMUS (Oxford, 2015). A study of British Council (2012) disclosed that the shift from the traditional destinations to host countries within the regions, e.g., to Singapore and South Korea, had recently intensified. South Korea reported $75 \%$ share of international students from the region, especially from China (MacGregor, 2014). China, India and South Korea are forecasted to remain the major source countries of outbound international students until 2020 and developed Asian countries with aging demographics, i.e., Hong Kong, Japan, Singapore and South Korea are likely to compete for larger international intakes in the future to offset the diminishing number of domestic students. An additional and also non-negligible reason is that the market for educational products and services is estimated to grow from a value of \$4.4 trillion in 2012 to $\$ 6.2$ trillion in 2017. The significance of this value is represented, e.g., by the US data, where international students contributed nearly $\$ 27$ billion dollars to the US economy only in 2014 that represents an increase of $12 \%$ compared to 2013 according to Ortiz et al. (2015).

Accordingly, internationalization of higher education in both countries became crucial to further development and a key to gain reputation for selected universities to compete with most renowned world-class universities in the environment of higher education rankings which are heavily biased towards Anglo-Saxon institutions. Internationalization has seemed to be unavoidable in this globalized and competitive environment of higher education. Thereby, both countries started to attract international students into their higher education institutions.

The industrial transformation of the city-state helped to build institutional and infrastructure capacity to put into effect the Global Schoolhouse Project, while many Asian countries lack of years of experience that the city-state gained. The establishment of World Class Universities was envisioned to be essential to contribute to niche centers of excellence in $R \& D$, transfer knowledge to the industry, and help the reputation of Singapore as global education hub (Education Workgroup, 2005). The pursuit towards world-class universities is regarded as further step within the nation-building strategy as people recognize the significance of human capital as the single source of development. Singapore's competitive advantage manifests in the early cognition of the importance of academic excellence. In contrary to the case in Singapore, the Korean higher education is likely to define internationalization "as a process of constructing a world-class higher education system via exchange of personnel and programs" and not as a "comprehensive endeavor to expand and integrate 
multicultural awareness into the institutional mission and policy framework" (Cho \& Palmer, 2013). Nevertheless, achievements showed rapid growth in publications and English became although controversial but an efficient driving force for Korean higher education internationalization.

The results of internationalization and of recruiting international students represent a mixed picture of success in both countries. The number of foreign tertiary students increased between 2012 and 2015 by $50 \%$ worldwide and the growth of the number of mobile international students in OECD countries only accounts for about 5\% between 2013 and 2014. Interestingly, during this one year period Korea's intake of foreign students decreased, still an overall long-term increase is observable (from 3,954 in 2000 to 104,262 in 2016) (Kim, 2016). The latest figures show an increase of about $18.6 \%$ in 2017 with 123,850 students in Korea (YNA 2018). The official goal of the Study In Korea Project has been (in 2004 to recruit 80,000 foreign students by 2008, 100,000 by 2012 and 200,000 by 2020) to set the number of foreign students for 200,000 in Korea by 2023 (Green 2015, ICEF 2015a). While the number of international students has been increasing in Korea, the number of outbound Korean students has been decreasing generally and the distribution of destinations has also largely changed with the rises of more affordable destinations (ICEF 2015b). Similar figure - to accommodate 150,000 international students - has been targeted by the government in Singapore as well (NAS, 2003). Yet, the numbers started to dip as other governments in the region followed the example of Singapore and attract global talents and are less costly.

Meanwhile, the government of the city-state had to retreat from the ambitious plans based on domestic political reasons (Gomes 2014, Basillote et al. 2016). Politicians had to react on negative comments on foreigners from Singaporean citizens and the government has taken steps by enhanced transparency to tackle the rising sentiment especially against international students. Still, full statistics on international students are not easily accessible. The government also has to demonstrate that in the immigration-based society of Singapore with aging problems must rely on further immigration (ERC, 2003). Such measures have not been vital to be taken as the significance of international students has not reached yet such a critical point as in Singapore. Due to Korea's more or less 'homogeneous society' ethnic conflicts and challenges of cultural diversity have not yet significant (Broward, 2009). Nevertheless, the leaders of South Korea ought to take proactive measures to prepare for potential hostility against international students. Both countries perceive their efforts to build an education hub as further measures for 'Nation Building' and as opportunity to develop their economies through participating and obtaining a leading role in knowledge-intensive sectors.

\section{Major Policies Geared Towards Global Higher Education Market}

In Singapore the government introduced the policy in 1965 that required students to study a second language compulsorily. Although the diversity of citizens allowed to use Chinese, Malay, Tamil and English languages, in the education English became the leading medium in schools. English became the major language to all students from 1987. On the one hand, the bilingual language policy imposed pressure on individuals using English and additionally Mandarin that replaced Chinese dialects in families with Chinese predecessors (Ho, 2015). On the other hand, Singaporean scholars discovered their potentials to publish researches in English, to participate in international researches and collaborations early. While in Singapore the bilingual education formed a foundation for rapid 
internationalization, Korea has needed to catch up. The corresponding pressure came from the government. To improve the quality of education and research the Minister of Ministry of Education, Science and Technology (MEST), Ju-Ho Lee, required that through policy the universities ought to increase and retain foreign faculty, increase pressure on Korean professors to publish in prestigious scientific international journals in English, to seek collaboration and exchange with international faculty and to use their infrastructure already in existence and develop it with scholars from other countries (Cho \& Palmer, 2013). Also, English-medium instruction (EMI) gained importance and newly appointed lecturers are to hold courses in English during a certain time in Korea.

The Prime Minister of Singapore Goh Chok Tong initiated reforms under the vision 'Thinking Schools, Learning Nation' (TSLN) in education to respond to the challenges of globalization from 1997 on. While the term 'Thinking Schools' refers to the process of "doing things through participation, creativity and innovation", 'Learning Nation' refers to a lifelong learning even beyond the boundaries of schools. The latter was needed to maintain competitive advantage within the region and serve demand for flexible labor in the country. Consequently, TSLN became a crucial vision that exists even today and supports continuous participation in the labor market. To avoid "over-massification" of universities (on the contrary that is represented by South Korea) Singapore has raised the cohort enrolment rate slowly and gradually and the rest of population could enroll at polytechnics and technical education providers. The education at these post-secondary institutes is inspired by the renowned German model of technical education with the advantage of EMI. Moreover, the Singaporean government widened tertiary education for its citizens through establishment of new private-public universities and also expanded degree programs and research activities at public universities. In addition, in 1998 Economic Development Board (EDB) commenced to invite at least ten World Class Universities to establish their degree programs in Singapore within 10 years (Education Workgroup, 2005).

To stay on developing into knowledge-based economy the government needed changes in curriculum and ensure quality in education. The International Academic Advisory Panel (IAAP) was set up in 1997 with the goal to support universities to transform into world-class institutions in terms of diversity, teaching and research. Based on the recommendations of IAAP the academic curriculum was redesigned with the emphasis on cross-faculty education to foster creative and critical mindset (MOE, 2001).

The establishment of IAAP was followed by the collaborative work between Singapore and Wharton School of Business at the University of Pennsylvania to establish the Singapore Management University (SMU) (Mok, 2003). New higher education institutions (SIT, SUTD, SUSS) were established to accommodate the growing number of university students as the gross enrolment rate (GER) increased from $25 \%$ to $40 \%$. These institutions were important in the development of the cluster for advanced knowledge source and could be also instrumentalized to further attract talented or fulltuition paying foreign students. The Singaporean government was committed to build a regional education hub with the focus on research and innovation. The city-state could build its plan on the regional education hub strategy to recruit international talents (students and scholars), creating partnerships with foreign universities and to collaborate in postgraduate programs and in research activities. The government attracted foreign universities to set up their campuses in Singapore. The aim has been to create a tertiary school sector that can compete with world-class universities all over 
INTERNATIONAL JOURNAL OF ACADEMIC RESEARCH IN BUSINESS AND SOCIAL SCIENCES Vol. 9, No. 1, Jan, 2019, E-ISSN: 2222-6990@ 2019 HRMARS

the world and to tap into the market of educational products and services. Accordingly, the government started to promote the competition between public universities and offshore campuses of renowned foreign universities. These efforts have been taken to remain highly competitive in the knowledge-based economy and increase attractiveness towards full-tuition fee paying international students (Natarajan et al. 2016).

Globalization guided and influenced governance in South Korea as well. Initially, policies were enacted to expand higher education by loosening enrolment quota policies. Internationalization policies were launched to convert Korea into an academic center in East Asia with renowned scholars from all over the world to continue their research activities in Korea to contribute to the country's knowledge generation (Cho \& Palmer, 2013). The reforms in South Korean education were introduced from 1993 and gained momentum due to the financial crisis in 1997. Due to the crisis the major shift from manufacturing economy towards knowledge-driven economy has been commenced. Similarly to Singapore's IAAP, the South Korea government set up Presidential Commission on Education Reform (PCER) in 1994 in order to reform education to cultivate "Koreans as prospective leaders for the 21st century".

Policies, starting with the 5.31 First Education Reform Plan in 1995, were launched to ensure the formation of a life-long, open-learning society (analogue to Singapore's TSLN effort). The establishment of an "Education Welfare State", also referred to as EDUTOPIA (as a result of the combination of education and place), has supported the education at any place and any time in one's life, has facilitated credit transfer among institutions and larger academic freedom with more opportunities for education to all (endeavored to transform the education system to become more responsive and dynamic to modifications of social and economic environments. Ideally the reformed education system would secure the knowledge creation through co-operative, creative and openminded manner and supports inventive ideas (UNESCO, 1998). Under this vision higher education has been reformed and the government has taken efforts to specialize and diversify colleges of universities and curricula were designed to improve critical thinking and creativity of students; and to standardize for higher level of autonomy. The Korean higher education has still remained quite rigid to respond to socio-economic changes. The crisis of 1997 forced the government to revise its approach and the Presidential Commission for the New Education Community (PCNEC) was established in June 1998. This commission was responsible to review and evaluate the progress of education reforms; to launch campaigns; to motivate citizens for education reform; and to initiate a bottom-up process for rectify reform processes (Mok, 2003).

The project Brain Korea 21(BK 21) can be divided into three phases, phase I (1999-2005) and phase II (2006-2012), and phase III (2013-2019). Phase I had three comprehensive goals: to foster the development of universities into world-class research universities which create knowledge and innovative technologies and accordingly to gear up specialization of universities; to expand the higher education in qualitative way by founding professional graduate schools and by improving quality of existing ones; and to improve the worldwide competitiveness of universities in terms of academic productivity and research output. It became the largest project in financial terms in the Korean higher education. The core area of education became science and technology. Phase II become more sophisticated in those goals and a few more were added: to create a national system of researchoriented universities; and to support to top-class scholars in the selected core areas; and financial 
INTERNATIONAL JOURNAL OF ACADEMIC RESEARCH IN BUSINESS AND SOCIAL SCIENCES Vol. 9, No. 1, Jan, 2019, E-ISSN: 2222-6990@ 2019 HRMARS

support was expanded to next-generation scientists at graduate level. Unsurprisingly, mostly universities with already advanced infrastructure and facilities became the major profiteer, i.e., the competition for financial support from the government was heavily biased. The selected universities were also supported and required to establish university-industry collaborations (Hur \& Bessey, 2013). Phase III has the ultimate goal to foster creativity, the development of creative economy. The plan was to support individuals on graduate level and to build a link between these and corporations. Suh and Park (2014) described the goals major goals of this project: to focus on global research development to increase quality publications (top $\mathrm{SCl}$ papers); to increase the quality of education and to achieve high-level expertise in focus areas and in inter-disciplinary departments.

The Brain Korea 21 project was extended by The Study Korea Project in 2004 that targeted the first time the process of internationalization with the impressive target of recruiting 50,000 international students by 2008 and 100,000 by 2012 (Green, 2015). The Study Korea Project was continued by the Study Korea 2020 Project from 2013 with the goals to increase number of foreign students to 200,000; to ensure quality education to boost competitiveness; and to generate recruitment plans (Ahn, 2012). The government was keen to improve quality of education and as a result also introduced related reforms: the quality assurance reforms 2007-2008 and the Disclosure of Higher Education Institution Evaluations for enhanced transparency in 2011. The plan 'Vision for Internationalization of Higher Education' in 2007 was launched to coordinate the work of eleven related ministries. This has helped the government to address and recruit foreign talents. The government also created programs for them, i.e., Global Scholarship Program (Choi, 2013). The World Class University Project (WCU) (2008-2012) intended to educate graduate students; to develop convergence technology; recruit worldwide renowned scientists, Nobel laureates to further improve the research output; to foster collaborations between Korean professors and foreign scholars; and to raise quality of education at the designated universities (Choi, 2013; and Jon \& Chung, 2013). An annual performance review, relevant measurement was the number of $\mathrm{SCl}$ journal article publications for both. Whereas in the case of WCU the beneficiary was the participating department and funding was open for graduate students, in the case of BK 21 grants were provided to graduate students, post-doctoral staff as well as junior faculty (Jang et al., 2016). WCU and BK 21 were merged into BK 21 PLUS due the efforts to lessen redundancies in incentive plans. Most recently, the Study In Korea Project - launched in 2001 and covering all government scholarship programs - has been run and coordinated by the National Institute for International Education (NIIED). The Online Education Fair was launched in 2015 with an originally announced number of 80 participating universities. Despite the announcement of 2015, the announced number of universities in the program stood at 25, but in 2018 the confirmed number of participating institutions (colleges and universities) increased to 53 (MOFA 2015, Study in Korea 2016 and 2018).

Undoubtedly, BK 21, WCU and the subsequent projects gave students a chance to receive scholarships, and supported regional universities to attract competitive and talented scholars (Han et al., 2018), but the lack of communication between stakeholders hindered collaboration between universities and industries. Additionally, strong intervention from the government seems to limit the autonomy of universities, and since only selected institutions of universities were funded, this has generated tension between participating and nonparticipating faculties (Jang et al., 2016). 
To design the aforesaid policies, governments need institutions which oversee education development and set goals for the future. The major government agencies in Singapore, which shape the higher education, the innovation system and deeply influence the strategy in establishing a competitive creative economy, are the Ministry of Trade \& Industry (MTI) and the Ministry of Education (MOE). MTI is responsible for managing R\&D activities through the agencies 'Enterprise Singapore' (merged with SPRING, i.e., Standards, Productivity and Innovation Board in 2018), EDB, A*STAR. SPRING was engaged in innovation and technology, management development, internationally-recognized standards. The government merged the two organizations to increase efficiencies and to exploit synergies of them. A*STAR describes itself as the agency with research institutes that develops talents and future leaders, assisting as bridge between academy and industry for increasing the efficiency in R\&D activities. It also works with MOE together in delivering a scholarship program for nurturing scientists for creative industries. MOE sees its task in policy making but also in fostering academic science and technology researches. The major government agencies in Korea are the Ministry of Education (MOE), the Ministry of Science and ICT (information communication technology) (MSIT), the Ministry of Economy and Finance (MOEF). MOEF is responsible for policy coordination and allocation of funds. MSIT focuses on increasing autonomy for research activities, securing resources which enable researches in convergent science and technology to face the requirements of Fourth Industrial Revolution. MOE in Korea is responsible for running all programs to attract talents for research and development to promote collaboration. The National Institute for International Education (NIIED) is an executive agency of MOE that promotes Korean scholarship programs for foreign talents, attracts international human resources with the goal to strengthen the national competitiveness in the globalized world. In a comparison, Singapore seems to define for a number of specific tasks in higher education a single organization with the aim of reducing complexity and achieve lean management, while in Korea the tasks remain mainly in the hands of MOE raising complexity within the organization. Still, Korea also discovered the importance of international education and established NIIED.

\section{Conclusion}

Singapore and South Korea saw the potentials for economic rise in manpower development. The progress of education in both countries went through developmental cycles based on the need for manpower much faster than in countries with well-established higher education. While South Korea preferred massification over qualitative education, Singapore still restricts the enrollment ratio to universities. Recently, competitiveness of higher education received priority as both countries rely heavily on immigration based on extremely low fertility rate: South Korea has one of the lowest fertility rate among OECD countries now (1.2 in 2016 according to OECD data) and Singapore has an even lower one (as it stood at 1.16 in 2017 (Au-Yong, 2018). Due to the rapidly decreasing number of domestic students, higher education is under constant restructuring in Singapore and Korea. Once education was defined as a service classified within GATS and sectoral liberalization took off, the citystate realized that the progress of higher education will not only contribute to the development of domestic creative economy, but also raises competitiveness internationally while attracting foreign talents, scholars and Nobel laureates. After the economic crisis of the end of 1990s the Korean 
government also had to acknowledge that a shift in education is necessary towards more autonomy for universities and knowledge generation for creative economy.

This comparative analysis revealed that both countries needed to grant their higher education larger share of autonomy, transfer of power and authority (decentralization) in exchange of tightened control and monitoring (re-)centralization. Furthermore, Singapore continued to develop a more diversified education with large share of vocational training and polytechnics, i.e., through top-down efforts higher education institutions were established or reconfigured and their tasks are widely defined. The city-state also welcomes collaboration between domestic and world-class established universities. The country also wanted to stimulate competition and support research activities with foreign universities. Therefore, it provided incentives to renowned foreign universities which opened their international branches in Singapore. The restructuring of higher education also encouraged the universities to generate income from different sources other than governmental funding the more sources they could integrate the larger funding government was willing to provide at the beginning. At the same time life-long learning projects were initiated: in Korea with the 'Lifelong Learning in Korea' of which the government runs the fourth plan (2018-2022) currently, and 'Thinking Schools, Learning Nation' which was announced in 1997. The South Korean government forced universities to decrease tuition fees and also increased its influence on universities. The consecutive governments implemented policies, such as Brain Korea $21 \mathrm{I}-\mathrm{II}$ and Brain Korea 21 PLUS, World Class University projects are aimed to qualitative progress of higher education and to raise ranking of Korean universities in order to be able to both attract foreign talents and to increase the research output to establish a solid basis for creative knowledge-based economy.

It became obvious for both countries that the formation of a real global education hub is a nearly impossible task, partly due to rising xenophobia and partly due to poor ranking. At the same time, they also realized that they can serve the regional markets even though competition has intensified. Singapore might have an advantage thanks to its long-term meritocratic governance based on its characteristic political situation. This provides continuity and consistency in education policy making as well. In contrast, Korea's changing political landscape may become a disadvantage in creating necessary long-lasting programs to sustain development in higher education. Further and deepened analysis may assist the Korean government to introduce projects with short-term goals in order to maintain consistency and efficiency.

Both of the countries Singapore and South Korea share similarities in history as well as in politics and in culture, yet differences led to a gap between their economies and quality of education. While Singapore opted for liberalized economy quite rapidly in its history, South Korea protected its industries and markets long till the Asian financial crisis. Additionally, the location-specific characteristics supported Singapore in globalization of its education market over South Korea. This comparative analysis discovered that both countries practice top-down approach in development. Nevertheless, Singapore seems to be more equipped to serve the demand of labour market than South Korea and what the lessons are for developing countries, if they are willing to progress in knowledge-based economies. The research contribution may assist policymakers in careful selection of policy instruments to use education well and develop their economies. However, this research could identify policies, reasons for astonishing improvement in economies of the two countries, it could also reveal a few flows. Further details and challenges could be discovered through additional 
INTERNATIONAL JOURNAL OF ACADEMIC RESEARCH IN BUSINESS AND SOCIAL SCIENCES

Vol. 9, No. 1, Jan, 2019, E-ISSN: 2222-6990 (C) 2019 HRMARS

analyses of the demand of industry sectors for skilled researchers and entrepreneurs, specifically through the emergence of large corporations and small and medium enterprises as the latter entities are the foundation of sound and sustainable economies.

\section{Acknowledgement}

The present research has been conducted by the Research Grant of Kwangwoon University in 2018.

\section{Corresponding Author}

Roland Attila Csizmazia

Academy of Advanced Studies, Kwangwoon University

Seoul, Republic of Korea

Email: csix@gmx.at

\section{References}

Ahn, A. T. (2012). Korea to attract 200,000 foreign students by 2020. The Korea Times, May 4, 2012. Retrieved on January 4, 2019 from http://www.koreatimes.co.kr/www/news/nation/2012/05/113_110310.html

Altbach, P. (2015). Asia's academic aspirations: Some problems. International Higher Education, Vol. 19, 7-8.

Au-Yong, R. (2018). Singapore's fertility rate down as number of singles goes up. The Straits Times, Sept. 28, 2018. Retrieved on January 4, 2019 from https://www.straitstimes.com/singapore/spores-fertility-rate-down-as-number-of-singlesgoes-up

Csizmazia, R. A. (2019). Singapore and Korea Towards Creative Economy in 21st Century: Comparative Analysis of Higher Education in Singapore and South Korea. International Journal of Academic Research in Business and Social Sciences, 9(1), 506-525.

Bahk, E. (2013). Private universities obliged to disclose financial data. The Korea Times, July 16, 2013. Retrieved on January 4, 2019 from http://koreatimes.co.kr/www/news/nation/2013/07/113_139353.html

Basillote, L., Gradus, Y., Lamb, J., Sharoni, T., \& Thng, M. (2016). Singapore's Higher Education Cluster. Harvard Business School. Retrieved on January 4, 2019 from http://www.isc.hbs.edu/resources/courses/moc-course-at-harvard/Documents/pdf/studentprojects/Singapore Higher Education 2016.pdf

British Council. (2012). The shape of things to come: higher education global trends and emerging opportunities to 2020. Going Global (2012). Retrieved on January 4, 2019 from https://www.britishcouncil.org/sites/default/files/the_shape_of_things_to_come__higher_education_global_trends_and_emerging_opportunities_to_2020.pdf

Broward, J. (2009). Korea at Tipping Point of Multicultural Society. The Korea Times, November 12, 2009. Retrieved on January 4, 2019 from http://www.koreatimes.co.kr/www/news/opinon/2009/11/160_55370.html

Christensen, S. (2015). Healthy competition and unsound comparison: reforming educational competition in Singapore. Globalisation, Societies And Education, Vol. 13, No. 4, 553-573. 
Cho, H. Y., \& Palmer J. D. (2013). Stakeholders' views of South Korea's higher education internationalization policy. Higher Education, Vol. 65, No. 3, 291-308.

Choi. S. (2013). CAMPUS Asia and its implications for university cooperation in Asia and EU: The Korean perspective. In Marx, A., Wouters, J., Moon, W., Rhee, Y., Park, S., \& Burnay, M. (Eds). EU-Korea relations in a changing world. Leuven: Leuven Centre for Global Governance Studies.

Csizmazia, R. A. (2016). Knowledge-Based economy - Rising challenges of the global schoolhouse project in Singapore. Mundo Asia Pacifico, 5(9). Retrieved on January 4, 2019 from http://publicaciones.eafit.edu.co/index.php/map/article/view/4441

Education Workgroup. (2005). Developing Singapore's Education Industry. Education Workgroup.

ERC. (2003). Report of the economic review committee: New challenges, fresh goals. Singapore: Ministry of Trade and Industry

European Commission. (2014). The Erasmus Impact Study. Effects of mobility on the skills and employability of students and the internationalisation of higher education institutions. Retrieved on January 4, 2019 from http://ec.europa.eu/education/library/study/2014/erasmus-impact_en.pdf

Tierney, W. G., \& Findlay, C. C. (2010). Globalisation And Tertiary Education In The Asia-pacific: The Changing Nature Of A Dynamic Market. Singapore: World Scientific.

Golden, G., \& Toledo, F. (2016). Education Policy Outlook - Korea. OECD 2016. Retrieved on January 4, 2019 from http://www.oecd.org/edu/Education-Policy-Outlook-Korea.pdf

Gomes, C. (2014). Xenophobia Online: Unmasking Singaporean Attitudes towards 'Foreign Talent' Migrants. Asian Ethnicity Volume15, No 1, 21-40.

Gopinathan, S. (2007). Globalisation, the Singapore developmental state and education policy: a thesis revisited. Globalisation, Societies and Education, Vol. 5, No. 1, 53-70.

Green, C. (2015). Internationalization, Deregulation and the Expansion of Higher Education in Korea: An Historical Overview. International Journal of Higher Education, Vol. 4, No. 3, 1-13.

Han, S., Kim, S., Seo, I., \& Kwon, K. (2018). An Analysis of Higher Education Policy: The Case of Government-Supported University Programs in South Korea. Asian Journal of Innovation \& Policy, Vol. 7, No. 2, 364-381.

Hultberg, P., Calonge, D. S., \& Kim, S. (2017). Education policy in South Korea: A contemporary model of human capital accumulation? Cogent Economics \& Finance, Vol. 5, No. 1 (2017), 1.

Hur, J.-Y. and Bessey, D. (2012). A comparison of higher education reform in South Korea and Germany. Asia Pacific Education Review, Vol. 14, No. 2, 113-123.

ICEF Monitor (2015a). Korea aims for 200,000 foreign students by 2023. Retrieved on January 4, 2019 from http://monitor.icef.com/2015/10/korea-aims-for-200000-foreign-students-by-2023/

ICEF Monitor (2015b). Number of Korean students abroad declines for third straight year. Retrieved on January 4, 2019 from http://monitor.icef.com/2015/02/number-korean-students-abroaddeclines-third-straight-year/

Jang D., Ryu K, Yi P, \& Craig D. A. (2016). The hurdles to being world class: Narrative analysis of the world-class university project in Korea. Higher Education Policy, Vol. 29, No. 2, 234-253.

Jon, J., \& Chung, H. (2013). STEM Report - Republic of Korea (STEM: Country Comparisons Contributing Consultants Reports). Australia: Australian Council of Learned Academies. 
INTERNATIONAL JOURNAL OF ACADEMIC RESEARCH IN BUSINESS AND SOCIAL SCIENCES

Vol. 9, No. 1, Jan, 2019, E-ISSN: 2222-6990 @ 2019 HRMARS

Retrieved on January 4, 2019 from http://acola.org.au/wp/PDF/SAF02Consultants/Consultant Report - Korea.pdf

Kang, S. (2010). Chadwick drawing international students. The Korea Times, August 6, 2010.

Retrieved on January 4, 2019 from

http://www.koreatimes.co.kr/www/news/nation/2017/06/113_70983.html

Kim, M. (2016). This year number of int'l students in South Korea breaks 100,000 for first time.

Hankyore, September 19, 2016. Retrieved on January 4, 2019 from

http://english.hani.co.kr/arti/english_edition/e_international/761712.html

Kim, T. (2007). Law on Private School to Be Revised Again. The Korea Times, August 6, 2007.

Retrieved on January 4, 2019 from

http://koreatimes.co.kr/www/news/nation/2007/08/113_7830.html

Knight, J. (2004). Internationalisation remodelled: definitions, approaches and rationales. Journal of Studies in International Education, Vol. 8, No. 1, 5-31.

Kwak, B. S. (2001). Leading the Future: Policy Directions and Tasks of Education in Korea, Seoul: Korean Educational Development Institute.

Lee, J. (2000). Main Reform on Higher Education Systems in Korea. Revista Electrónica de Investigación Educativa, Vol. 2, No. 2, 61-76.

Lee, M. (2008). The PISA Results and the Education System in Korea. Korea Institude of Curriculum \& Evaluation. Retrieved on January 4, 2019 from http://www.isei-

ivei.net/eng/evaleng/ponencias-ingles/educaiton_in_Korea_MKLEE.pdf

Lee, M., \& Gopinathan, S. (2008). University Restructuring in Singapore: Amazing or a Maze? Policy Futures In Education, Vol. 6, No. 5, 569-588.

MacGregor, K. (2014). The shifting sands of international student mobility. University World News, 334. Retrieved on January 4, 2019 from

http://www.universityworldnews.com/article.php?story=20140912112348627

Ministry of Education Singapore. (2000). The Knowledge Economy and Universities. Retrieved on January 4, 2019 from http://www.nas.gov.sg/archivesonline/speeches/view-

html?filename $=2000010702 . \mathrm{htm}$

Ministry of Education Singapore. (2001). International Academic Advisory Panel Third Meeting In Singapore, 8-11 January 2001. Retrieved on January 4, 2019 from

http://www.nas.gov.sg/archivesonline/speeches/view-html?filename=2001010605.htm

Ministry of Education Singapore. (2003). Restructuring of Singapore's University Sector (EDUN N2834-009 V5), May 28, 2003. Retrieved on January 4, 2019 from http://www.nas.gov.sg/archivesonline/speeches/view-html?filename=2003052806.htm

Ministry of Education Singapore. (2005). Preliminary Report of the Steering Committee to Review University Autonomy, Governance and Funding. Retrieved on January 4, 2019 from http://www.nas.gov.sg/archivesonline/speeches/view-html?filename=2005010693.htm

Ministry of Education Singapore. (2012). Greater Diversity, More Opportunities in Singapore's University Sector. Retrieved on January 4, 2019 from https://www.moe.gov.sg/news/pressreleases/greater-diversity--more-opportunities-in-singapore-s-university-sector

Ministry of Education Korea. (2015). 2015 Plan for Ministry of Education. Happy Education for All, Creative Talent Shapes the Future. Retrieved on January 4, 2019 from http://english.moe.go.kr/ 
INTERNATIONAL JOURNAL OF ACADEMIC RESEARCH IN BUSINESS AND SOCIAL SCIENCES

Vol. 9, No. 1, Jan, 2019, E-ISSN: 2222-6990 @ 2019 HRMARS

Ministry of Education Korea. (2016). Happy Education for All. Creative Talent Shapes the Future. Retrieved on January 4, 2019 from http://english.moe.go.kr/

Ministry of Education Singapore. (2016). Education Statistics Digest 2016. Retrieved on January 4, 2019 from https://www.moe.gov.sg/docs/default-source/document/publications/educationstatistics-digest/esd-2016.pdf

Ministry of Manpower. (1999). Launch of Manpower 21 plan, National Archives of Singapore (NAS). Retrieved on January 4, 2019 from http://www.nas.gov.sg/archivesonline/speeches/viewhtml?filename=1999083105.htm

Ministry of Foreign Affairs. (2015). 2015 Online Education Fair Korea. Retrieved on January 4, 2019 from http://overseas.mofa.go.kr/aten $/ \mathrm{brd} / \mathrm{m} \_8362 /$ view.do?seq $=724558 \& \mathrm{srchFr}=\&$ srchTo=\&srchWord=\&srchTp=\&multi_itm_seq $=0 \& i t m \_s e q \_1=0 \& i t m \_s e q \_2=0 \&$ company_cd $=\&$ company_nm $=\&$ page $=4$

Mok, K. (2003). Decentralization and marketization of education in Singapore: A case study of the school excellence model. Journal of Educational Administration, Vol. 41, No. 4, 348-366.

Moon, M., \& Kim, K. (2001). A case of Korean higher education reform: The Brain Korea 21 project. Asia Pacific Education Review, Vol. 2, No. 2, 96-105.

National Archives of Singapore. (2003). Speech by George Yeo, Minister for Trade and Industry, at "Singapore - The Global Schoolhouse". Retrieved on January 4, 2019 from http://www.nas.gov.sg/archivesonline/speeches/view-html?filename=2003081602.htm

Natarajan, U., Hoe Yeong, L., \& Gopinathan, S. (2016). Globalization and Higher Education. The Changing Context and Landscape in Singapore. THF Working Paper, Working Papers Series No.3/2016. Retrieved on January 4, 2019 from http://www.headfoundation.org/papers/_2016_3)_Globalization_and_Higher_Education_The_ Changing_Context_and_Landscape_in_Singapore.pdf

OECD. (2016). PISA 2015 High Performers -Singapore. OECD. Retrieved on January 4, 2019 from https://www.oecd.org/pisa/PISA-2015-singapore.pdf

OECD. (2018) Education at A Glance 2018: Korea. Retrieved on January 4, 2019 from http://gpseducation.oecd.org/Content/EAGCountryNotes/KOR.pdf

Ortiz, A.; Chang, L. and Fang, Y. (2015). International Student Mobility Trends 2015: An Economic Perspective, World Education News \& Reviews. Retrieved on January 4, 2019 from http://wenr.wes.org/2015/02/international-student-mobility-trends-2015-an-economicperspective

Osman-Gani, AM. (2004). Human Capital Development in Singapore: An Analysis of National Policy Perspectives. Advances in Developing Human Resources, Vol. 6, No. 3, 276-287.

Sidhu, R., Ho, K., \& Yeoh, B. (2011). Emerging education hubs: the case of Singapore. Higher Education, Vol 61, No. 1, 23-40.

Shin, B. T. (2014). A Global City on Singaporean Soil: Growing the Economy, not the Gap? Lee Kuan Yew School of Public Policy, Case Studies. Retrieved on January 4, 2019 from http://shinbint.com/writing/Singapore_Global_City.pdf

Singstat. (2018). Education, Language Spoken and Literacy. Retrieved on January 4, 2019 from https://www.singstat.gov.sg/find-data/search-by-theme/population/education-languagespoken-and-literacy/latest-data 
INTERNATIONAL JOURNAL OF ACADEMIC RESEARCH IN BUSINESS AND SOCIAL SCIENCES

Vol. 9, No. 1, Jan, 2019, E-ISSN: 2222-6990 (C) 2019 HRMARS

Study in Korea Fair. (2016). Online Study in Korea Fair (2016) Retrieved on January 4, 2019 from http://www.studyinkorea.go.kr/en/expo/help_info.do?expo_no=40

Study in Korea Fair. (2018). Online Study in Korea Fair (2018) Retrieved on January 4, 2019 from http://www.studyinkorea.go.kr/fr/expo/cyber_expo_past_detail.do?expo_no=46

Suh, G. and Park, S. (2014). The Korean Government's policies and strategies to foster world-class universities. In Ying Cheng, Qi Wang and Nian Cai Li (eds.), How World-Class Universities Affect Global Higher Education: Influences and Responses. Sense Publishers, 65-83.

Tan, K.P. (2008). Meritocracy and Elitism in a Global City: Ideological Shifts in Singapore. International Political Science Review, Vol. 29, No. 1, 7-27.

Teng, A. (2016). SCCCI to give \$1.2m each to five unis. The Straits Times, September 10, 2016. Retrieved on January 4, 2019 from http://www.straitstimes.com/singapore/education/sccci-togive-12m-each-to-five-unis

Toh, M.-H. (2012). Internationalization of tertiary education services in Singapore (ADBI Working Paper Series No. 388). Asian Development Bank Institute. Retrieved on January 4, 2019 from https://papers.ssrn.com/sol3/papers.cfm?abstract_id=2161691

UNESCO. (1998). Education Management Profile - Republic of Korea. Unesco Principal Regional Office for Asian and Pacific, Bangkok. Retrieved on January 4, 2019 from http://unesdoc.unesco.org/images/0011/001135/113539eo.pdf

UniSIM. (2017). http://www.unisim.edu.sg/Pages/index.aspx

YNA. (2018) No. of foreign students in S. Korea grew at record-high 18 pct last year: data. Yonhab News Agency, February 5, 2018. Retrieved on January 4, 2019 from https://en.yna.co.kr/view/AEN20180205003200315 